\title{
The Library at the University of Western Ontario
}

Mr. Landon, who directs the library he describes, is also a historian and author of Western Ontario and the American Frontier and Lake Huron.

U

NIVERSITIES have from early times become the depositories for treasures of literature, the arts, and the sciences. It was a Sir Thomas Bodley who in 1597 began to build up for Oxford University the collection of books that has since grown into the Bodleian Library, one of the world's great treasure houses. It was a John Harvard who at his death in 1638 gave a bequest of eight hundred pounds and something over three hundred volumes as a foundation for the New England college which through the years has become one of the chief universities of the world and whose library is the richest in resources of any university in the Western Hemisphere.

The library of the University of Western Ontario, at London, had its Bodley in the person of John Davis Barnett. Born in England, he came to Canada in 1866 to become a draftsman for the old Grand Trunk Railway. $\mathrm{He}$ advanced to become a mechanical superintendent and during most of his life was actively engaged in such duties, but from his first arrival in Canada until his death in 1924 he was an assiduous collector of books and other bibliographical material. When in 1918 he gave his accumulations to the University of
Western Ontario, the bound volumes exceeded forty thousand. In addition, there were many thousands of pamphlets, maps, prints, and other miscellaneous items which added greatly to the value of the collection. His only stipulation was that the university should adopt a liberal policy with respect to loans to persons outside the institution. This has been consistently carried out, with the result that residents of Western Ontario have access to many scarce or specialized books and journals which they could not reasonably expect to find in any public library.

The library of the University of Western Ontario had but meager resources when the Barnett collection came in 1918 . The administration, realizing the value of this gift, made immediate provision for its development by proper classification and cataloging and by expanding the library services generally. The books had been singularly well chosen and probably 90 per cent were suitable for university use. During the years between 1918 and his death in 1924 Dr. Barnett continued to expand his holdings, and by his will he made a substantial bequest to the library.

Looking back to the coming of this gift, the first large benefaction ever received by the university, it can be seen that it had two important effects. It was almost at once followed by other benefactions for which it had set an example. Furthermore, the character of the gift influenced later 
library policy in a number of ways. The Barnett books, for example, were rich in such fields as Canadiana and Americana, Shakespeariana, English literature, and folklore. The scope of these sections suggested that they should be continuously developed. Small endowments received through the years have provided income which can be specially applied to such portions of the library.

More interesting, however, is the influence which the Barnett gift has exerted in other directions. The large stores of prints and illustrations laid the foundation for a practical working collection in the field of art. The maps, many of them of early Canadian and American significance, provided the foundation for a department that has since developed extensively. Magazine excerpts, selected over half a century and carefully classified, provided much unusual material. A graduate student who brought a list of over one hundred references on one of the nineteenth-century poets was astonished to find more than threequarters of them in one single parcel. Thus, Barnett left more than a large private library of books. He laid the foundation for special services which are noticeable today in the activities of the library.

\section{Art Department}

The art department, of which mention has been made, contains few rare prints such as an art gallery might possess. But it does contain thousands of reproductions, gathered from varied sources and classified so that they can be made of practical use. The instructor in English, for example, who desires pictorial material relating to William Blake can be supplied with reproduction of that author's paintings, facsimiles of title pages and text of his books, and with portraits of the man himself. From the archeological material, largely clipped from duplicate files of the Illustrated London News and other journals, may be drawn a variety of illustrations of classic architecture, art, costume, and the landscapes of those countries embraced in what we call the Ancient World. Apart from such classroom uses, the art room constantly supplies material for exhibitions in the library itself.

In addition to its stores of pictures the art room contains, also files of clippings and magazine articles on the artists themselves, on musical composers, and on actors, as well as the archeological material mentioned above. The pictures relating to Shakespeare fill several drawers of a vertical file, classified first as to play, then by the leading characters, and finally under such general headings as stage setting and costume. The general collection on costume is also in this department.

The development of such departments within a library of moderate size is usually feared as likely to involve a considerable expense. But this is not necessarily so. At the time when the art collection at Western Ontario was in its first stages of organization, an extensive purchase was made of vertical files and other secondhand equipment discarded by a large life insurance company which was refurnishing its offices. The supply was sufficient to meet all needs for years ahead. There is a suggestion here for other libraries, since the postwar period will probably bring a large volume of office equipment to the market, discarded from government departments whose activities are ceasing.

\section{Manuscripts}

From time to time the library has acquired extensive collections of manuscript material. One of the most interesting of these consists of the diaries and papers of the Rev. James Evans, the Wesleyan missionary 
who a hundred years ago devised the Cree syllabic characters which gave to those Indian tribes of the Canadian Northwest their first form of writing. At Norway House, far north on Lake Winnipeg, Evans printed portions of the Bible for the use of his Indian charges, using birchbark and skin when paper was not to be had, making his type from the lead linings of tea chests, his ink from lampblack and fish oil, and utilizing an old fur press for the printing operations. Specimens of his work are rare and highly valued. Some portions of the papers in this collection have been printed by the Ontario Historical Society.

A second important group of papers are those of the Hon. David Mills, who rose from humble schoolteaching in one of the Western Ontario counties to be minister of justice for Canada and later a justice of the Supreme Court of the Dominion. Mills entered Parliament in 1867 , the year of Confederation, and in the political events of the next thirty years he was a conspicuous figure.

There are other similar collections of some magnitude, but along with them have come a constant flow of individual documents or small collections of documents, chiefly related to the history of the peninsula lying between Lakes Huron and Erie and the Georgian Bay-Western Ontario. A few years ago the library received the records contained in Middlesex County Court House (Middlesex being the county in which London is situated). Documents covering a period of almost a century were included in this large accession, which was almost immediately followed by receipt of the records of the county of Huron, lying immediately to the north. As the two counties differed in a marked way in origin and background, the two groups of papers supplemented rather than duplicated each other.
The organization and development of these papers and of extensive collateral material (pamphlets, broadsides, etc.), has resulted in the collection of regional history, housed separately in the library and directed by Elsie M. Murray, a specialist in this field. The regional collection is designed to illustrate the social and economic development of Western Ontario. It contains a variety of material that would be lengthy to describe. Records of early municipal bodies, courts, business enterprises, and religious organizations are naturally included. Diaries, private letters, etc., tell much of the life of earlier days. Photographs culled from old-fashioned albums show the costume of preceding generations. Programs of lectures, debates, and musical events record the cultural growth of the area.

\section{Publications}

Western Ontario, like nearby states in the republic, has reached the age when it is becoming increasingly conscious of its past. Local historical societies flourish in the province, and the university, through its regional collection, is cooperating in their work. A mimeographed publication, issued quarterly and distributed without charge, bears the title Western Ontario Historical Notes. In content it is exactly what the title indicates. It contains short articles on local history, an occasional original document, news of the societies, and a popular Notes and Queries section.

A second publication coming from this branch of the library has as title $W$ estern Ontario History Nuggets. Four of these have so far been distributed, each being either a separate little study or the reproduction of a document. The second issue, for example, was a bibliography of the newspapers of one of the counties within the university's area. The library itself possesses an extensive collection of Canadian 
newspapers and also a considerable file of American newspapers of the Civil War era.

London is in the center of one of the richest agricultural areas of eastern Canada and its university is, therefore, much interested in the problems of the farm. It is interested also in the history of agriculture, and the collection of earlier agricultural journals at London is probably the most extensive in Canada, comprising not only Canadian titles but also many of those of the Eastern states. Before the distinctively Canadian farm journals reached any considerable circulation such American journals as the Genesee Farmer, the Ohio Farmer, the Cultivator, etc., had many subscribers in the province of Ontario and doubtless exercised some measure of influence upon farming practice. It is important, therefore, that they should be preserved in a Canadian library just as they are preserved in American libraries. The Western Ontario holdings of American farm journals have been chiefly acquired by exchange with other libraries in the United States.

\section{Religious Histories}

There are two other sections of the library to which attention might be drawn. The first of these is the Canadian denominational religious history. There are larger separate collections of Methodist history or Presbyterian history or Baptist history in other Canadian libraries, but probably nowhere else will so much be found in one place relating to the religious past of the country. This includes scarce early journals and records of the various church assemblies. As one aspect of social history, this Canadian field will bear wide cultivation.

A final section of the library which deserves mention is that of American history. There are extensive and complete files of many of the state historical journals. The collection of books on slavery is large and includes a lengthy file of the African $R e$ pository, organ of the American Colonization Society. Curiously, a portion of that society's own file of this journal has found its final resting place in this Canadian library. For several of the states there is a considerable amount of local history on the shelves.

Prior to 1934 the general library of the University of Western Ontario had a succession of temporary homes. In the decade prior to 1934 it was housed on two floors of a portion of the main university building. In the latter year, however, the present Lawson Memorial Library was opened, honoring the names of Frank Lawson, a London businessman, and his wife, by whose bequest the erection of the building was made possible. In its floor plans it bears some resemblance to the University of Michigan Library, though, of course, on a much reduced scale. The main reading room on the second floor seats 200 , while other reading rooms and carrells provide for an additional 125 readers. The stacks were designed to hold about I 70,000 volumes, but as that capacity will be strained within the next few years plans are now under way for expansion.

The Lawson Memorial Library, in addition to its reading rooms, has an art and music room, a newspaper room, a rare book room, and a museum of North American archeology. The museum, of which Wilfrid Jury is honorary curator, is a center from which extensive archeological work has been carried out in Western Ontario, and several bulletins have been published setting forth the results of excavations. Groups of students are occasionally taken on exploratory expeditions and given some acquaintance with the proper methods of excavating Indian village sites.

Though the museum is primarily devoted 
to Indian archeology, it has in recent years expanded the scope of its collecting to include objects illustrating the pioneer life of Western Ontario. When articles, such as farm implements, are too large for exhibition, models have been made to scale and given a proper setting. A reproduction in miniature of a pioneer $\log$ cabin and its outbuildings, together with examples of furniture, etc., forms one of the most interesting of such groups so far assembled. Another is a reproduction of a Huron Indian village of the early seventeenth century. These small-scale reproductions have been found effective in conveying through the eye the details of social life of the past. They are the work of Mr. Jury and his father, Amos Jury. The latter, a farmer by occupation, is talented as a painter in water colors and also does exquisite modeling in clay.

The library of the medical faculty of the University of Western Ontario, housed in the medical school building, is outstanding in Canada in the richness of its collections of journals. But it, too, has sqme features that are of more general interest. It has, for instance, a large historical section built up through the years which, while not possessing any of the great treasures in its field, does include many items of considerable interest. Two editions of Dr. William Beaumont's record of his experiments in gastric research are among the American items. They take us back to the day when the young FrenchCanadian Alexis St. Martin received a gunshot wound in the stomach and was nursed back to life and health by the scientificallyminded army surgeon on Mackinac Island. The observations which Dr. Beaumont was enabled to make through the open wound (which never closed) brought important advances in physiology and form one of the bases of the modern study of dietetics.
In addition to its historical collection, the library has a growing collection of bookplates, much of it related to medicine, and also a collection of medical portraits. It has gone far, too, in the building up of scrapbook collections on subjects related to its work. In the local historical field extensive investigations have been carried on by a London physician connected with the medical school staff, Dr. Edwin Seaborn, whose new volume on the history of the profession in Western Ontario will appear in the next few months. Dr. Seaborn's collection of notes and other data on the subject of his book will be deposited in the medical school library.

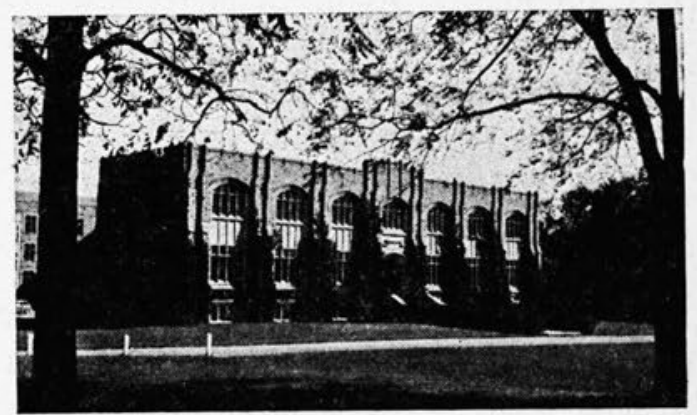

Lawson Memorial Library

The most recent building added to the campus at the university is the McIntosh Memorial Art Gallery, opened in 1942. Its activities are closely related to those of the library. The building, a very gem of architecture, was provided for in the will of Mrs. Wilhelmina McIntosh as a memorial to her husband, John Gordon McIntosh, and herself. She also bequeathed to the university her collection of pictures, about fifty in all, and provided an endowment both for the upkeep of the gallery and for the purchase from time to time of additions to the collection.

Mrs. McIntosh's own pictures were chiefly of the French and British schools of the later nineteenth century, and no de- 
cision has yet been made as to the field or fields in which development should take place. London, though a city of less than one hundred thousand population, is blessed with two art galleries, the civic gallery being in the new Williams Memorial Public Library. Here chief emphasis has been placed upon loan exhibitions, changed monthly and continuous throughout the year. The two London galleries work in close cooperation, a condition which prevails in equal degree as between the public library and the library of the university.

The McIntosh Gallery, in addition to its primary purpose, is also the headquarters of the Western Ontario Conservatory of Music, affiliated with the university, and is used for musical lectures and recitals. It contains the extensive collection of records which was provided by the Carnegie Corporation and also a small musical library of biography, criticism, and miniature scores. The university library also has an extensive collection of books in the field of music.

The libraries of this university have as their primary function the meeting of such regular needs as arise in an institution with an enrolled student body of about two thousand. These needs have the first call upon the staff and resources. But the library administration has not hesitated to explore paths more commonly regarded as possible only in a library of larger size and with greater resources. What has been done at Western Ontario represents, therefore, the adaptation of such activities to a smaller institution and the carrying out of plans by economical methods. The results of such ventures as have been undertaken have been considered profitable. The building up of the regional collection of history, for example, has attracted wide attention in the province and has brought considerable "corn to the bin." Outside contributors provide most of the copy for the issues of Western Ontario Historical Notes. Many gifts for the regional collection have come from the same sources.

A word might be added concerning the exchange of duplicates which has been carried on extensively with other libraries for many years past. Over the last ten years the library has added about one thousand volumes annually from this source and has disposed of as many or more to other institutions. All exchanges have been upon a rough piece-for-piece basis, making for a minimum of recording.

\section{Years Ahead}

In all that has been done, the years ahead have been kept in mind. There is no regular department of art at this university as yet, but when such a department does come, as it probably will within the next few years, there will be much needed material assembled, classified, and ready for use. In the same way the regional collection will provide valuable material for graduate work in history. Already it is giving stimulus to local historical work in the province, as well as serving the professional ranks.

It would be improper to convey the impression that any of the specialized departments of this library which have been mentioned are in any state other than that of development. Most of the activities are still in the experimental stage, perhaps the most interesting stage of all. None of them would have been possible without the presence on the staff of men and women who had the spirit of adventure and were themselves enthusiastic over the things which they were doing. Mistakes have been made, processes have had to be discarded, but enough has been realized and brought to fulfilment to give constant encouragement to go yet farther. 